\title{
The Development of Authentic Assessment Model for the Learning of Drama Text Appreciation Skill among High School Students in Padang: A Strategy for Youth Character Building
}

\author{
Nurizzati $^{1}$, Ena Noveria ${ }^{2}$, Ermawati Arief $^{3}$ \\ \{nurizzati2138-@fbs.unp.ac.id\} \\ 1,2,3Universitas Negeri Padang, Jl. Prof. Dr. Hamka Air Tawar Padang Sumatera Barat 25131, \\ Indonesia
}

\begin{abstract}
The learning and evaluation of literature appreciation in the classroom are still not optimal. The measurement kits for learning appreciation of literature are mostly only up to the level of knowledge (cognitive) whilst the psychomotor and affective domains are inadequate. Therefore, this study aims to develop an authentic assessment model for Basic Competencies in the literary text of drama based on the 2013 Curriculum for high school. The development of the assessment of drama text appreciation is essentially begun by conducting a needs analysis, basic competency analysis, material analysis, and student analysis. The design of implications development follows the Basic Competencies of learning drama texts appreciation include understanding, abstracting, producing, and comparing texts, as well as aspects of language in Curriculum 2013. The development model taken is the 4-D consisting of define, design, develop, and dissemination.
\end{abstract}

Keywords: appreciation skill, drama text, the development of authentic assessment model, authentic assessment instrument, linguistic aspects of 2013 Curriculum.

\section{Introduction}

Assessment is the third main task of the teacher and carried out following the assessment principles that should have been prepared including the lesson plan and a series of materials developed in the learning process. If the teacher implements the concept of authentic assessment, the teacher must be prepared with cognitive, psychomotor and affective domain assessment instruments during the learning process. This assessment requires a processstandard measuring tool to determine the level of student achievement consisting of a grid of test material, questions or tests, scoring guidelines, and answer keys [1]. The 2013 curriculum defines assessment as the process of documenting knowledge, skills, attitudes, and beliefs in a structured manner [2],[3],[4].

Assessment is the process of gathering the information that is used to make decisions about educational policies or curriculum quality, the quality of the educational process, the quality of inputs and products or about the mastery of students regarding something that has been taught to them [5],[6],[7]. According to Brown [8], Assessment is an ongoing process that encompasses a much wider domain. Then, the test is a subset of assessment. Airasian [9] stated that assessment is the process of collecting, synthesizing, interpreting information to aid in decision making". McMillan agreed with this definition and emphasizes it by asserting: "The broader, more inclusive, the definition is better because it places such task as making up 
a test, administering it, and scoring the result in a larger context that includes interpretation and use of the results".

According to Johnson and Johnson [10], the purpose of the assessment is to trigger the teachers to have the instruments for (a) diagnosing the level of knowledge and skills of students; (b) monitoring progress to achieve the learning objectives to help produce learning programs; (c) providing data to assess the final level of student learning.

The development of models and authentic assessment tools for competency learning in literary texts (drama) appreciation is necessary for effective literary appreciation learning in the classroom. The conducive and measurable learning model for drama appreciation with reliable instruments will be able to build and explore students' sensitivity and concern for their lives and social environment [11]. Referring to the opinion of experts, in a well-organized language and literacy learning, students are given the opportunity to demonstrate the ability to use language, such as speaking, reading out loud, and writing various forms of essay [12]; [13];[14];[15];[16];[17];[18]; students are prepared and given the opportunity to practice appreciating literary works in class, starting from understanding, abstracting, producing and comparing following the stages of text-based Indonesian learning [19].

Conceptually, the types of authentic assessment developed for the learning of drama texts can bring a fun, challenging, and enhance learning atmosphere and increase students' enthusiasm for the appreciation of literary works, and in an extended level, for creating literary works [3],[20] Teachers, together with students, build knowledge, give meaning, seek clarity, be critical, communicate, and be able to justify the literary works. Learning becomes a process that helps students to think correctly and logically because the instruments given to students train and allow them to think in their ways. Students' ability to think adequately is more important than answering questions correctly. In order for an individual (student) to reach the level of thinking correctly and logically, he must understand the argument of logic which consists of three parts, namely the rationale or reality of the ground, the argument or how to place the basis shared thoughts, and the conclusions or results achieved by applying arguments to the rationale [21]. This will give an experience to students to love the world of work that they will later face in professional life.

\section{Methods}

This study is categorized as research and development and commonly called R \& D. It aims to produce certain products and test the effectiveness of the products so that they can function in the wider community [22]. The development model used as a guideline is a learning development model suggested by Thiagarajan, Semmel, and Semmel [23] the 4-D model [24]. This model consists of four stages, namely define, design, develop and disseminate which is converted into the assessment development theory proposed by Earl and Katz [4]. The development of the learning assessment model for the ability to appreciate the drama text is carried out in three stages: (1) the initial stage, namely the formulation of the problem and the theoretical study, a description of the empirical conditions of assessment carried out in the field, and analysis of students; (2) the advanced stage, the model development stage; and (3) the model trial in the sample schools as the third stage.

\section{Discussion}


The define stage in developing an authentic assessment of learning the ability to appreciate drama texts that refer to the 4-D model is the initial situation explanation stage, namely the empirical facts of student and teacher perceptions in State High Schools No. 3 Padang which were collected by questionnaire. The assessment data included in the teacher's lesson plan is also used to reveal the empirical facts of the assessment.

The design stage of research on assessment development in drama text appreciation learning for High School level in Padang is designing an assessment instrument following the concept of authentic assessment. The authentic assessment model developed is shown in the following chart.

LEARNING ASSESSMENT MODEL FOR TEXT (DRAMA) APPRECIATION SKILL BY USING AUHENTIC ASSESSMENT 
A.

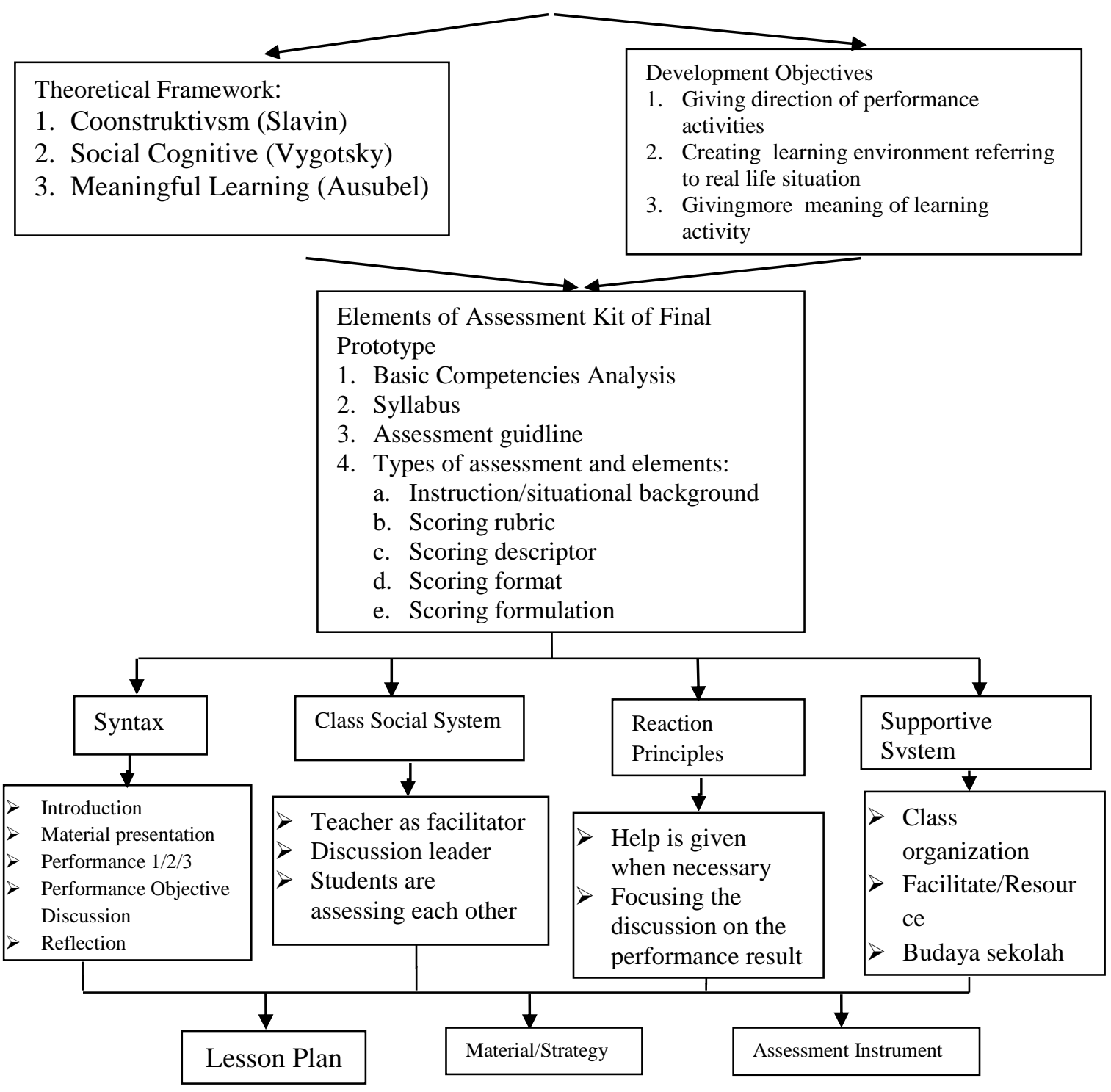

The development of authentic assessment models of learning the ability to appreciate literary texts (drama) is based on supportive learning theories, such as constructivism theory, 
social cognitive theory, and meaningful learning theory. The theory of constructivism emphasizes that learning activities are efforts to build new knowledge on an old knowledge framework. The use of authentic assessment instruments in constructive learning helps students practice building meaning from the knowledge they have gained in the learning process.

In social cognitive theory, knowledge can be obtained by students effectively through interaction with others in joint activities, and this idea reflects the view that cognitive functions originate from social situations. While learning theory is meaningful, learning is a process of linking new information to relevant concepts contained in a person's cognitive structure. Ausubel believes that teachers must be able to develop students' cognitive potential through meaningful learning processes wherein they are involved in many activities directly. However, students are subjects of learning that must be active.

The syntax or arrangement of learning implementation with an authentic assessment model as an instrument to guide activities in class is shown in the following table. The define stage in developing an authentic assessment of learning the ability to appreciate drama texts that refer to the 4-D model is the initial situation explanation stage, namely the empirical facts of student and teacher perceptions in State High Schools No. 3 Padang which were collected by questionnaire. The assessment data included in the teacher's lesson plan is also used to reveal the empirical facts of the assessment.

The design stage of research on assessment development in drama text appreciation learning for High School level in Padang is designing an assessment instrument following the concept of authentic assessment. The authentic assessment model developed is shown in the following chart.

\begin{tabular}{|c|c|c|}
\hline \multicolumn{3}{|c|}{ Syntax of Drama Text Appreciation Learning } \\
\hline STEP & TEACHER ACTIVITY & STUDENTS ACTIVITY \\
\hline $\begin{array}{l}\text { Step 1 } \\
\text { Description of } \\
\text { authentic tasks }\end{array}$ & $\begin{array}{l}\text { Describing learning tasks that } \\
\text { assessed by using authentic } \\
\text { assessment rubric and } \\
\text { managing comfortable } \\
\text { formation of students in the } \\
\text { classroom. }\end{array}$ & $\begin{array}{l}\text { Listening and paying attention to } \\
\text { teacher explanation about the } \\
\text { authentic tasks that must be } \\
\text { finished }\end{array}$ \\
\hline $\begin{array}{l}\text { Step } 2 \\
\text { Description of } \\
\text { material that each } \\
\text { part of it is guided } \\
\text { by the authentic } \\
\text { assessment rubric }\end{array}$ & $\begin{array}{l}\text { Explaining the material that } \\
\text { each part of it is assessed with } \\
\text { authentic assessment rubric }\end{array}$ & $\begin{array}{l}\text { Listening and paying attention to } \\
\text { teacher explanation about the } \\
\text { material that each part of it is } \\
\text { assessed with authentic assessment } \\
\text { rubric }\end{array}$ \\
\hline $\begin{array}{l}\text { Step } 3 \\
\text { The implementation } \\
\text { of learning by } \\
\text { using the guideline } \\
\text { of performance } \\
\text { assessment kit } \\
1 / 2 / 3 \text { or other types } \\
\text { of authentic } \\
\text { assessment. }\end{array}$ & $\begin{array}{l}\text { Conducting the step by step } \\
\text { learning and discussing the } \\
\text { learning materials following } \\
\text { the guideline of performance } \\
\text { assessment kit } 1 / 2 / 3 \text { or other } \\
\text { authentic assessments }\end{array}$ & $\begin{array}{l}\text { Conducting the step by step } \\
\text { learning and discussing the learning } \\
\text { materials following the guideline of } \\
\text { performance assessment kit } 1 / 2 / 3 \text { or } \\
\text { other authentic assessments }\end{array}$ \\
\hline $\begin{array}{ll}\text { Step } 4 & \\
\text { Discussion } & \text { o }\end{array}$ & $\begin{array}{lcc}\text { Guiding } & \text { the discussion } & \text { of } \\
\text { students } & \text { competence } & \text { or }\end{array}$ & $\begin{array}{l}\text { Conducting the discussion on the } \\
\text { tasks that has been done or doing }\end{array}$ \\
\hline
\end{tabular}




\begin{tabular}{|l|l|l|}
\hline $\begin{array}{l}\text { performance } \\
\text { achievement }\end{array}$ & $\begin{array}{l}\text { students performance for } \\
\text { assessment or conducting } \\
\text { interview and conference }\end{array}$ & $\begin{array}{l}\text { performance or interview and } \\
\text { conference with teachers }\end{array}$ \\
\hline $\begin{array}{l}\text { Step 5 } \\
\begin{array}{l}\text { Feedbackof score } \\
\text { achievement/ } \\
\text { students score }\end{array}\end{array}$ & $\begin{array}{l}\text { Processing the achievement } \\
\text { score and consult it with } \\
\text { students }\end{array}$ & $\begin{array}{l}\text { Accepting teacher's explanation } \\
\text { about the achievement and have } \\
\text { consultation about the result }\end{array}$ \\
\hline
\end{tabular}

The class social system is a description of the position or role of teachers, students, and support systems. The position of the teacher and the student is equal. Both have their roles. The implementation of their roles is assisted by the device. The teacher's role is supported by lesson plans, teaching materials, and assessment instruments, as well as a support system consisting of classroom organizations, resource facilities, and school culture. The teacher's role in helping students obtain learning experiences is to create a variety of situations and learning methods while utilizing assessment instruments as learning tools [26]; [27].

The following is a Class Social System chart with an authentic assessment model

\begin{tabular}{|c|c|}
\hline Teacher's roles & Students' activities \\
\hline $\begin{aligned}> & \text { As an administrator } \\
> & \text { As an facilitator } \\
> & \text { As a moderator } \\
> & \text { As acommentator } \\
> & \text { As a feedback contributor } \\
& \text { (Reflection) }\end{aligned}$ & $\begin{array}{l}\text { Work in team } \\
\text { Be responsible for fulfilling } \\
\text { the group assignment } \\
\text { Exchange ideas } \\
\text { Measure other students, } \\
\text { performance } \\
\text { Help each other }\end{array}$ \\
\hline $\begin{array}{l}\text { Learning Kits } \\
\qquad \begin{array}{l}> \\
>\end{array} \text { Material } \\
>\text { Assessment instrument }\end{array}$ & $\begin{array}{l}\text { Supporting systems } \\
\quad \text { Class organization } \\
>\text { Facility/resource } \\
>\text { School culture }\end{array}$ \\
\hline
\end{tabular}

As presented in the chart, the type of learning model interaction in drama text appreciation is designed in a multi-directional pattern; from teacher to student, student to teacher, and student to student. The help is given by the teacher if necessary. Learners are focused on discussing performance results. Performance results that have been corrected by the teacher are communicated again to students. Teachers also give a note of improvement or praise if the results of student performance are good.

The following chart illustrates the principle of learning reactions.

\section{TEACHER}




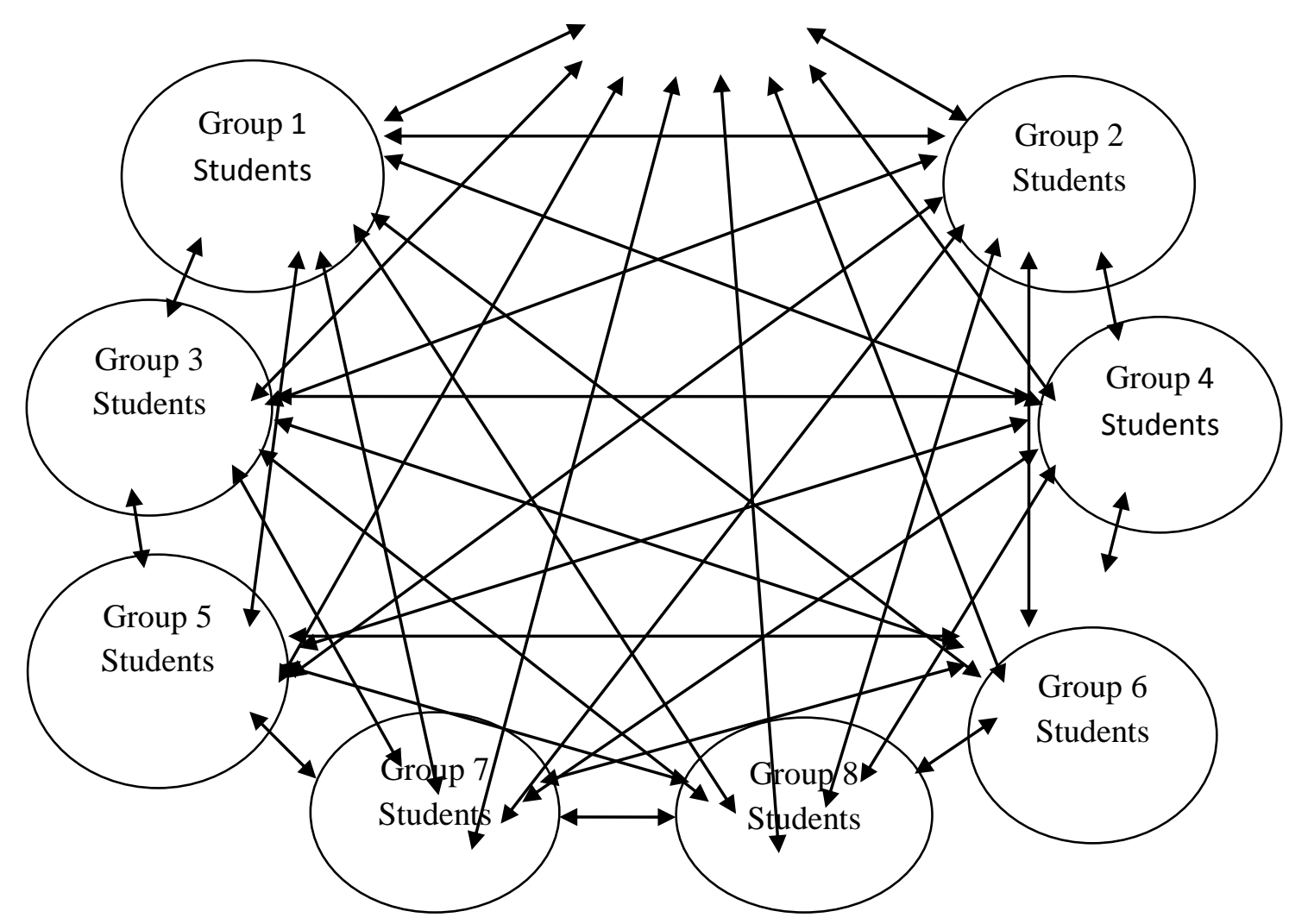

The develop stage is a designdevelopment stage that has been composed. There are 3 things that need to be explained at this stage: philosophical foundation, development phase, and limited trials. The philosophical foundation for the development of authentic assessment tools for the ability to appreciate drama texts is supportive learning theories, such as constructivism theory, social cognitive theory, and meaningful learning theory, as explained earlier.

In line with the substance of the development meaning, an authentic assessment tool for learning the ability to appreciate drama texts was developed in 4 phases. The four phases are integrated into the research procedure as listed in the following chart and explained in detail.

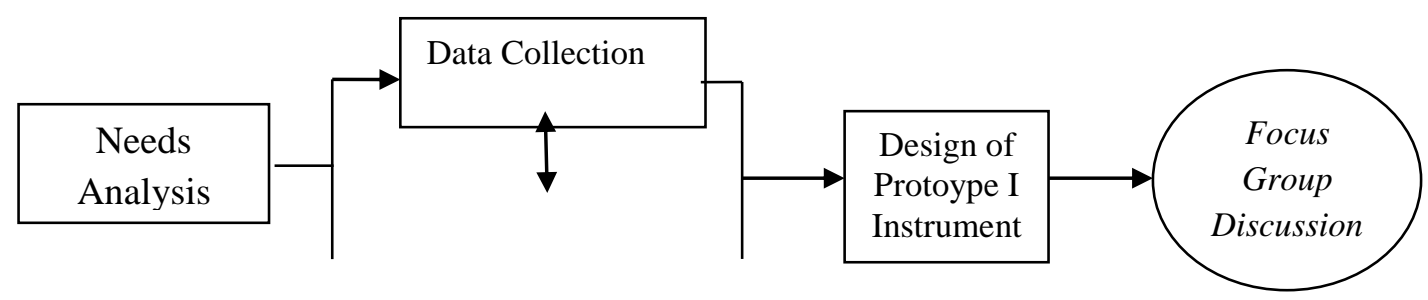




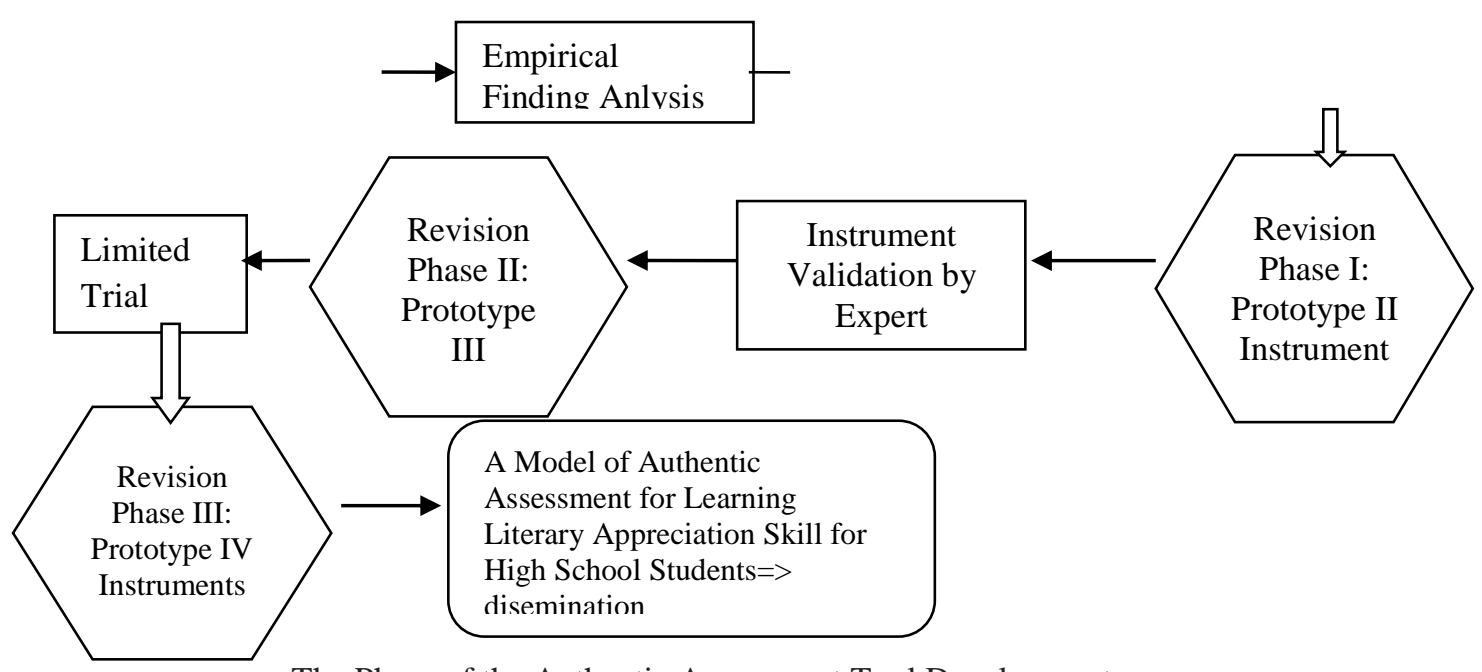

The Phase of the Authentic Assessment Tool Development

Phase 1 produces a prototype device I which was compiled based on the theory of the development of learning tools conceived by authentic assessment experts. The components of the prototype I include: (1) indicators and learning objectives; (2) Syllabus; (3) assessment indicators; and (4) instrument kit. The instrument kit consists of: (a) instructions; (b) assessment rubric; (c) scoring descriptors; (d) scoring format; (e) score calculation formula. The closing component of all devices is the score recapitulation format and the formulation for one unit mastery final score calculation.

Phase 2 produces a prototype II device which is produced based on the revision of phase I. Phase I revision is a made after receiving criticism and input from Focus Group Discussion (FGD) forums attended by assessment experts, lecturers of Indonesian Language and Literature Education department, and Indonesian language and literature high school teachers which become the partner of researcher. The prototype II device is submitted to the validator to be validated.

Phase 3 produces an authentic assessment tool for learning the ability to appreciate the prose (drama text). The prototype III is a result of improvement based on notes and suggestions from the validator. The process of repairing the devices referring to the phase II revised material is done by carefully reading the notes made by the validator and contemplating the oral suggestions. The prototype III device was tested limitedly. The limited trial data is used as a reference to conduct extended trials which are also called the dissemination stage (Phase 4).

Based on the concept of literary appreciation learning that is in line with the learning of literary skill, the models and devices developed to reach a high level of appreciation and creative appreciation. The development of authentic instruments of the ability to read, analyze and interpret drama texts reaches a high level of appreciation. Meanwhile, the instrument development of writing skills based on drama text reading achieves creative appreciation. Both are high levels of appreciation. Additionally, following the aspects of the competence that must be learned in Indonesian Language and Literature subjects, the developed authentic assessment model is used to assess the training of listening, speaking, reading, writing, serving, and reviewing, as well as instruments that measure the development of the noble character of learners. 
The instrument device that indicates low appreciation, as well as the beginning of the drama appreciation activity, is the assessment of retelling story (abstracting/reviewing). In this activity, students only retell and review the contents of a text according to their understanding of the text. The text appreciation is being carried out when students are able to identify the elements of the text they have read, or perform reading comprehensively, rhythmic vocals, and performances that support comprehension and vowels in beautiful reading.

A high level of appreciation is obtained with an authentic assessment instrument of the ability to appreciate drama texts that analyze the relation of intrinsic elements with extrinsic elements. This instrument requires students to be able to connect the reality in the drama text with the reality within the life of the community, particularly the society told in the drama text that the students read. Based on the students' efforts to connect the reality in the drama text with the reality within the life of the community, they interpret the values that can be used as guidance for their lives. For this matter, Marx, et.all [28] stated that reading skill is a substantial prerequisite for lifelong learning and implemented in almost all aspects of human life. The activity of reading drama texts can be maintained to practice the students' ability to abstract, interpret values or portray the character of the characters depicted in the drama text.

Achieving a high level of appreciation is obtained with an authentic instrument of instrument assessment of the ability to appreciate drama texts that analyze the relationship of intrinsic elements with extrinsic elements. This instrument requires students to be able to connect the reality that is in the drama text with the reality that is in the life of the community, especially the society told in the drama text that the students read. Based on the students' efforts to connect the reality in the drama text with the reality in the life of the community they interpret the values that can be emulated and guided for their lives. For this matter, Marx, et.all [28] suggested that reading skills are an important prerequisite for lifelong learning and participating in almost all aspects of people's lives. The activity of reading drama texts can be continued to practice the students' ability to abstract, interpret values or portray the character of the characters depicted in the drama text.

In accordance with the logic of the development, the learning process for drama text appreciation begins with reading examples of drama script. After that, the students write their own drama script, design the cast, play the characters, and finally converts the nine types of authentic assessment can be developed, namely: (1) The assessment of retelling the content of the text, which aims to to train students' ability to memorize and tell a story coherently and completely as well as the framework of the drama script based on their own memorable events or experiences. The learning model is implemented with a group pattern by designing characters/roles as many as group members; (2) The performance appraisal, which is developed to guide students to compile and develop the framework of a drama script into a complete script (a series of dialogues describing a set of events includes conflict, character development, and story completion); (3) The assessment of investigative projects, which purposes to asses the creativity of students to design the perform their drama scripts on stage; (4) The assessment of interview and conference. The topic of the interview follows the assessment indicators of investigative projects carried out by students such as (a) the management of the play (for example, a childish face is chosen to play a child character, the quiet is chosen as a mother, etc.); (b) the relevance of the role play to the substance of the story through the dialogue (the role of costumed and formal or authoritative teachers, the role of costumed and modest head of dormitories, etc.); (c) the planning of the role authenticity (the acting performance is as natural as possible with full appreciation) (5) the assessment of the verbalization and role of dialogue, namely reciting conversations between characters following the required vocals or pronunciation by following the linguistic rules: phonological, 
morphological, and syntactic supported with the intonation of literary language, as well as the ability of students to portray and say the dialogue of their characters (role acting); (6) the performance evaluation converts drama texts to poetry texts which if possible and desirable can also be accompanied by evaluations of the poetry's beautiful reading performance; (7) the assessment of open response questions, conducted as a complementary material for learning material in cognitive skill category. This assessment is done by giving several questions to measure students' comprehension and knowledge about drama. These questions require students' open responses.

The full assessments focusing on the learning process and contributes to affective domain assessment are self-observations and peer evaluation which are categorized as the 8th and 9th authentic assessments. The process assessment is an assessment conducted in and during the learning process. Observation assessments are carried out by the teacher. Additionally, self-assessment and peer-assessment are carried out by students. Each assessment is developed into 2 types following the goals or objectives. Type 1 is an assessment of students' participation and their perseverance in the learning process and assessment of students' character and social skills. This pattern is also developed for selfassessment of students and peers.

\section{Conclusion}

An assessment that is often simplified as scoring is one of the important activities in education and learning today because assessments that are planned, structured, and carried out effectively determine the level of success in achieving curriculum objectives. The 2013 curriculum that is based on contextual aspects indicates the need for an assessment of the process. Thus, each achievement of student behavior change can and must be assessed appropriately. The process-based assessment is well known as an authentic assessment using the assessment rubric instrument.

In line with linguistic learning, literacy learning is basically also useful for language practice in understanding the types of authentic assessment. The learning of drama text appreciation will be more effective by following types of authentic assessment: (1) The evaluation of retelling the contents of the text; (2) The performance evaluation of developing drama scripts; (3) The assessment of project investigations; (4) The interview and conference evaluation; (5) The verbalization and participation in drama on stage; (6) The assessment of converting drama texts into poetry; (7) The open response questions; (8) The observation assessment; and (9) The self and peers evaluation. All of these types of assessments potentially integrate simultaneous literacy and language skills training.

\section{References}

[1] Djiwandono, Soenardi. Language Test: A Handbook for Language Teachers. Jakarta: PT. Indeks. 2011.

[2] Mulyasa, H.E. Implementation of Education Unit Level Curriculum. Jakarta: Bumi Aksara. 2009.

[3] Nurgiantoro, Burhan. Authentic Assessment. Yogyakarta: Gadjahmada Press. 2011.

[4] Atmazaki. Alternative Assessment in Indonesian Language Teching. Padang: UNP Press. 2013

[5] Yusuf, A. Mury. Fundamentals and Techniques of Educational Evaluation. Padang: UNP Pres. 2005 
[6] Nurizzati, "Development of Autentic Assessment Tools Model of Reading Literature Skill of Padang City Student Junior High School". Dissertation Research Report. Padang: LP2M. 2015.

[7] Nurizzati. "Authentic Assessment Tool Development Learning Ability compose of Reading and Writing Aspects for Padang City Junior High School Students". Dissertation. Padang: Concentration of Indonesian Education, Science Education Program, Graduate University of Padang. 2017.

[8] Brown, Douglas. Language Assesment. San Fransisco: Longman. 2004.

[9] McMillan, James H. Formative Classroom Assesment. Columbia: Teachers College Press. 2007.

[10] Johnson and Johnson. Meaningfull Assesment. Boston: Allyn and Bacon . 2002.

[11] Mahayana, Maman. "Appreciation of Indonesian Literature in Schools" Susastra 5, Journal of Literature and Culture Vol. 3. Number 5. Jakarta: Obor Foundation. 2009.

[12] Schulz, Melissa M. "Effective Writing Assessment and Instruction for Young English Language Learners". Oxford: Jurnal Early Childhood Educ J 37:57-62 DOI 10.1007/s10643-009-0317-0. Downloaded, in January 12, 2017. 2009.

[13] Atac, Bengu Aksu. 2012. "Foreign Language Tachers' Attitude Toward Authentic Assessment in Language Teaching”. The Journal of Language and Linguistic Studies Vol.8, No 2. Downloaded, in January 12, 2017.

[14] Shahrakipour, Hassan . "On the Impact of Self Assessment on EFL Learners' Receptive Skills Performance". International Research Journal of Art \& Humanities (IRJAH). Downloaded, in January 12, 2017. 2013.

[15] Mahmoud, Abdulmoneim. "Learner Involvement in Language Development: From Course Design to Performance Assessment". Journal of Language Teaching and Research, Vol. 4, No. 4, pp. 679-683, July 2013. Downloaded, in January 12, 2017. 2013.

[16] Alharbi, Majed Abdulkareem. "Reading Strategies, Learning Styles and Reading Comprehension: A Correlation Study". Journal of Language Teaching and Research, Vol. 6, No. 6, pp. 1257-1268, November 2015. Diunduh, 12 Januari 2017. 2015.

[17] Agabao, Rischell G and Guaiab, Marisa. "Learning Activities in Studying Literature". International Refereed Research Journal, ww.researchersworld.com. Vol.-V, Issue-3, July 2014. Downloaded, 12 Januari 2017. 2014.

[18] Channa, Mansoor Ahmed dan Nordin, Zaimuariffudin Shukri. "Social Cognitive Theory And The Zone Of Proximal Development In The Learning Of Reading Comprehension". Sci.Int.(Lahore),27(1),581-585, 2015. Downloaded, in January 12, 2017. 2015.

[19] Mahsun. Texts in Teaching Indonesian Language of 2013 Curriculum. Jakarta: PT Raja Grafindo Persada. 2014.

[20] Santrock, John W. Education Psychology. (Translated by Tri Wibowo B.S.). Jakarta: Kencana. 2008.

[21] Albrecht, K. Thinking Power. Semarang: Dahar Prize. 1992.

[22] Sugiyono. Educational Research Methods Quantitative, Qualitative and $R \& D$ Approaches. Bandung: Alfabeta. 2009.

[23] Thiagarajan, S., Semmel, D. S., \& Semmel, M. I. Instructional development for training teachers of exceptional children. 1974

[24] Trianto. Integrated Learning Model: Concepts, Strategies, and Their Implementation in Education Unit Level Curriculum. Jakarta: Earth Literacy. 2012. 
[25] Sukardi. Educational Evaluation: Principles and Operations. Jakarta: Bumi Aksara. 2009.

[26] Kunandar. Professional Teachers: Implementation of Education Unit Level Curriculum (SBC) and Success in Teacher Certification. Jakarta: Raja Grafindo Persada. 2011.

[27] Nurizzati, Noveria, and Arief. "Development of Autentic Assessment Model Learning Achieving Skill of Literary Text High School Student Of Padang City: One Strategy For The Establishment of Young Generation Character". Research Report. Padang: LP2M. 2018.

[28] Marx, Alexandra, et.all. "Components of Reading Comprehension in Adolescent Firstlanguage and Second-language Students from Lowtrack Schools". Springer Science+Business Media: Dordrecht 2015. Downloaded, in January 12, 2017. 2015. 